\title{
Subdoses of 2,4-D Choline Salt on Yield Components in Function of the Soybean Growth Stage
}

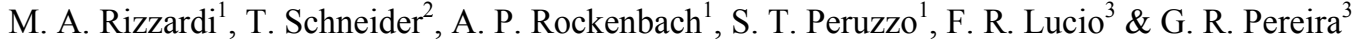 \\ ${ }^{1}$ University of Passo Fundo, Passo Fundo, RS, Brazil \\ ${ }^{2}$ University of Cruz Alta, Cruz Alta, RS, Brazil \\ ${ }^{3}$ Corteva Agriscience, São Paulo, SP, Brazil \\ Correspondence: Theodoro Schneider, University of Cruz Alta, Cruz Alta, RS, Brazil. Tel: 55-55-99948-4293. \\ E-mail: theodoroschneider@hotmail.com
}

Received: April 30, 2019

doi:10.5539/jas.v11n13p199

Accepted: June 10, 2019 Online Published: August 15, 2019

URL: https://doi.org/10.5539/jas.v11n13p199

The research is financed by Corteva Agriscience.

\begin{abstract}
Residues of herbicide tanks may cause damage to sensitive crops. The objective of this study is to evaluate the potential effects of subdoses of the herbicide 2,4-D choline salt on the vegetative and reproductive stages of soybean. The experiment was randomized blocks with a subdivided plot design and four replications. The application times were at V3 and R2 in the main plot. The herbicide 2,4-D choline salt was applied at the subdoses $0,2.28,4.56,9.12,18.24,27.36$ and $45.60 \mathrm{~g}$ a.e. $\mathrm{ha}^{-1}$ in the subplots. Phytotoxicity was evaluated at 3,7 and 14 days after application (DAT) of treatments, soybean height at 14 and 28 DAT and at ripening, yield components at ripening, and grain yield. The phytotoxicity evaluation of 2,4-D choline salt evidenced that symptoms were only observed up to 14 days after application (DAT) of treatments. The 2,4-D did not affect any of the variables tested. Grain yield was not influenced by application times or subdoses.
\end{abstract}

Keywords: Glycine max, residues, synthetic auxins, phytotoxicity

\section{Introduction}

In recent years, genetic improvement companies have developed several crops with resistance to herbicides aiming to fight the increase in the occurrence of herbicide resistant weeds (Vink et al., 2012). The availability of multi-resistant cultivars allows farmers to integrate new management strategies to control a wider range of weed species, even resistant biotypes, preserving resistant crops. Resistance to glyphosate is an example (Green \& Castle, 2010; Vink et al. 2012).

Among the new technologies of resistance to herbicides, soybean and corn crops genetically modified to resist applications of 2,4-dichlorophenoxyacetic (2,4-D) have been tested, and should be available in the Brazilian market in the coming years. The 2,4-D herbicide is an auxin mimic herbicide that has been used worldwide to control several dicotyledonous weeds for over forty years (Behrens et al., 2007).

Such herbicides affect cell wall plasticity and nucleic acid metabolism and activate auxin response genes, leading to the overproduction of ethylene and subsequently abscisic acid (Kelley et al., 2004; Grossmann, 2010; Shaner, 2014). The increase in abscisic acid leads to stomatal closure, limiting the assimilation of $\mathrm{CO}_{2}$, followed by inhibition of growth (Grossmann, 2010). The most common symptoms of soybean auxin mimic herbicide subdoses are stem and leaf epinasty, swollen and cracked stems, chlorosis, and necrosis (Andersen et al., 2004; Kelley et al., 2005).

With the introduction of 2,4-D-tolerant soybean cultivars, the occurrence of a spraying containing residues of these herbicides in a tank is inevitable and predictable. Such symptoms occur with cultivars without genes tolerant to active ingredients based on 2,4-D, causing injuries and reductions in grain yield (Olszyk et al., 2015).

Soybean is a plant sensitive to 2,4-D-based herbicides, especially when exposed at the reproductive stage (Slife, 1956). The literature reports that the application of $140 \mathrm{~g}$ a.e. $\mathrm{ha}^{-1}$ does not affect grain yield of soybeans when applied at the V3 stage. However, there is an $11 \%$ decrease in yield due to the application of $70 \mathrm{~g}$ a.e. $\mathrm{ha}^{-1}$ at 
soybean flowering (Wax et al., 1969). However, in recent literature, there is little information on its behavior for current cultivars in function of sensitivity to 2,4-D.

Information related to sensitivity of soybean to 2,4-D tank residues during vegetative and reproductive stages is little known in Brazilian environmental conditions. Analyses of yield components may be useful to quantify such effects. Extensive studies have shown that the number of nodes, the number of pods, and the weight of grains are the main contributors to high yields.

Thus, the evaluation of yield components is necessary to assist in determining the relationship between soybean exposure to auxin mimic herbicides and grain yield at different stages of development. The determination of the effects of the application of 2,4-D residues in spraying tanks on non-tolerant soybean cultivars helps to provide soy producers and pesticide applicators with information on the potential risk of injuries and on the reduction of soybean grain yield.

The hypothesis of this work is that soybean is susceptible to 2,4-D, causing a decrease in grain yield. Thus, the objective of this study is to evaluate the potential effects of subdoses of the herbicide 2,4-D choline salt on the vegetative and reproductive stages of soybean.

\section{Material and Methods}

\subsection{Plant Material and Experimental Conditions}

The experiment was conducted at the experimental field of the University of Passo Fundo (UPF), located in the middle plateau of Rio Grande do Sul, Brazil. The mean altitude of the experimental area is $678 \mathrm{~m}$, and the geographical location is $28^{\circ} 12^{\prime} 59^{\prime \prime} \mathrm{S}$ and $52^{\circ} 23^{\prime} 37^{\prime \prime} \mathrm{W}$. The soil of the experimental area is typical dark red (Embrapa, 2006), and the climate of the region is characterized as subtropical humid with a hot summer (Cfa) according to the climatic classification of Köppen. Before the installation of the experiments, twenty days before sowing, glyphosate was applied in the whole area $\left(1,080\right.$ g a.e. ha $\left.^{-1}\right)$ to eliminate weed vegetation in the area. The sowing of soybean (Syngenta IPRO) was carried out in December 2015. The line spacing was $0.45 \mathrm{~m}$, and the population was 280.000 plants $\mathrm{ha}^{-1}$.

During the conduction of the experiments, rainfall totaled $1,365.2 \mathrm{~mm}$, which is higher than the climatological normal for this period, which is $855.0 \mathrm{~mm}$ (Figure 1). The average air temperature in this period was $21.21{ }^{\circ} \mathrm{C}$, which is within the climatological normal of $20.5^{\circ} \mathrm{C}$ for these months (Embrapa, 2016).

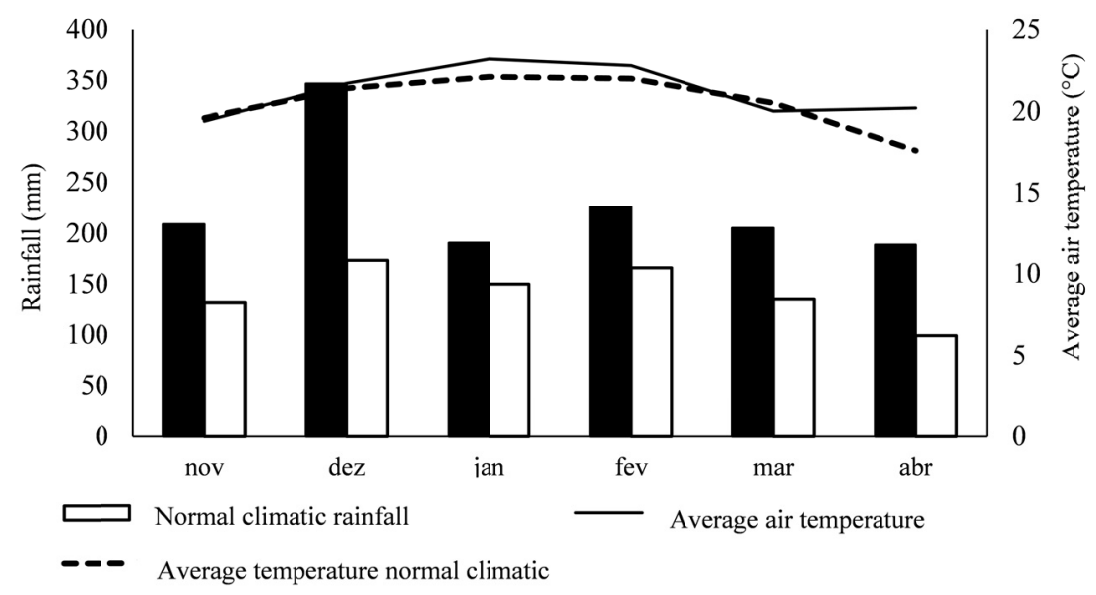

Figure 1. Rainfall monthly, normal climatological rainfall, average monthly air temperature, and average normal climatological temperature during the experimental period. Passo Fundo, RS. 2016

\subsection{Experimental Design and Treatments}

The experimental design was randomized blocks arranged in subdivided plots with four replications. The plots were five meters in length and 3.5 meters in width. The main plot represented the stages of application of soybean (V3, represented by the third node of the stem with developed leaves, and R2, represented by the flowers in the last four nodes of the stem with developed leaves). The subplots represented the subdoses of herbicides. The herbicide 2,4-D choline salt (GF-3073), at the subdoses $0,2.28,4.56,9.12,18.24,27.36$ and 45.60 g a.e. ha $^{-1}$, represented 0 , $0.25,0.5,1,2,3$ and $5 \%$ of the commercial dose, respectively. 


\subsection{Procedures}

The herbicides were applied when the soybean plants reached the desired stages of development (V3 and R2). For this, a backpack spray, pressurized with $\mathrm{CO}_{2}$, provided with fan-like tips $\mathrm{AD} 110.015$, calibrated to provide an application volume of $150 \mathrm{~L} \mathrm{ha}^{-1}$ of herbicidal syrup, was used. Phytotoxicity was evaluated 3, 7, 14 and 28 days after the application of treatments (DAT) using a percentage scale, where zero represented absence of symptoms and one hundred the death of plants (Table 1) (Frans et al., 1986; Robinson et al., 2013). At 14 and 28 DAT, the height of ten plants within the useful area of the plot was measured from the base of the main stem to the node of the last trefoil emitted.

At harvest ripening, ten plants were collected within the useful area of each plot to measure height, number of nodes in the main stem, number of branches, total number of pods, and weight of one thousand seeds. The mean values of the ten evaluated plants were used for data analysis purposes. In addition, grain yield was determined by harvesting the three central lines in the useful area of the plot using a mechanized plot harvester.

Table 1. Scale of classification of visual injury in soybean plants affected by auxin mimic herbicides (Robinson et al., 2013)

\begin{tabular}{|c|c|}
\hline Escala & \\
\hline 0 & No injury, plant growth is normal. \\
\hline 10 & $\begin{array}{l}\text { Slight reduction in height or canomy volume, cupped or bubbled leaves on less than ore qual to the upper } 10 \% \text { of the plant, bent } \\
\text { petioles, and, chlorosis or necrosis. }\end{array}$ \\
\hline 20 & $\begin{array}{l}\text { Moderately crinkled leaflets (extended across less than or equal to the upper } 20 \% \text { of the plant), curled petioles, reduced height and } \\
\text { canopy volume, cupped terminal leaflets. }\end{array}$ \\
\hline 30 & $\begin{array}{l}\text { Moderate to high reduction of height and canopy; compacted internodes and plants begin to have an abnormal appearance; } \\
\text { malformation with drawstring, fiddleneck, or cupped effects on less than or equal to the upper } 30 \% \text { of the plant; many petioles } \\
\text { curled and main stems may be bent. }\end{array}$ \\
\hline 40 & $\begin{array}{l}\text { Highly stunted plants (less than or equal to } 40 \% \text { of the plant), petioles curled and main stems bent or starting to curl, upper leaves } \\
\text { exhibit severe malformation and expansion of new leaves suppressed, plant may have patches of necrotic tissue. }\end{array}$ \\
\hline 50 & $\begin{array}{l}\text { Very high reduction of plant height (less than or equal to } 50 \% \text { of the plant) with little likelihood of recovery from the apical } \\
\text { meristem, new growth suppressed, formation of pods reduced or malformed, some leaf and stem tissue becomes necrotic, petioles } \\
\text { and stems show severe twisting. }\end{array}$ \\
\hline 60 & $\begin{array}{l}\text { Severe height and canopy reduction, including any new growth from axillary buds; leaves severely cupped or fiddlenecked on less } \\
\text { than or equal to } 60 \% \text { of the plant; petioles and stems twisted, swollen, and splitting; more extensive die-back of tissue.. }\end{array}$ \\
\hline 70 & $\begin{array}{l}\text { Severe to very severe reduction of plants, new growth callused and inhibited, most leaves severely deformed and mostly necrotic, } \\
\text { extensive petiole bending. }\end{array}$ \\
\hline 80 & $\begin{array}{l}\text { Very severe soybean injury, less than or equal to } 80 \% \text { of the plants mainly prostrate, petioles twisted with leaves drooping, leaves } \\
\text { chlorotic or necrotic, stems severely twisted, swollen, and split. }\end{array}$ \\
\hline 90 & $\begin{array}{l}\text { Plant dying, less than or equal to } 90 \% \text { of the plants mainly prostrate, leaves and stems mostly chlorotic or necrotic, all petioles } \\
\text { severely twisted, swollen, or split. }\end{array}$ \\
\hline 100 & All plants dead. \\
\hline
\end{tabular}

\subsection{Statistical Analysis}

The data were analyzed for normality (Shapiro Wilk test), and later were subjected to analysis of variance ( $\mathrm{p} \leq$ 0.05 ). For the variables phytotoxicity at 3, 7, 14 and 28 DAT and height at 14,28 DAT and at ripening, the Tukey test was performed at $5 \%$ of error probability when a statistical significance was observed. For the variables number of nodes of the main stem, number of branches, number of pods, weight of one thousand seeds and yield, in case of statistical significance, a regression analysis was performed.

\section{Results and Discussion}

\subsection{Symptoms of Phytotoxicity}

The symptoms of soybean phytotoxicity caused by the 2,4-D herbicide were observed at the doses 27.36 and 45.60 g a.e. $\mathrm{ha}^{-1}$ at the 3 and 7 DAT evaluations for application at V3 and R2 (Table 2). In evaluations at 14 DAT, the phytotoxicity was $8 \%$, only perceptible at the highest subdose and when applied at the V3 stage. At 28 DAT, the symptoms of phytotoxicity were no longer visually perceptible in any of the herbicide subdoses and application times (data not shown). 
Table 2. Phytotoxicity (\%) of soybean at 3, 7 and 14 days after application of treatments (DAT), cultivar Syngenta 13561 IPRO, in function of the application of subdoses of the herbicide 2,4-D choline salt and growth stages of soybean. Passo Fundo, RS, 2016

\begin{tabular}{|c|c|c|c|}
\hline \multirow{2}{*}{ Dose $\left(\mathrm{g}\right.$ a.e. $\left.\mathrm{ha}^{-1}\right)$} & \multicolumn{2}{|c|}{ Growth Stage } & \multirow{2}{*}{ Average } \\
\hline & V3 & R2 & \\
\hline \multicolumn{4}{|c|}{ Phytotoxicity at $3 \mathrm{DAT}$} \\
\hline 0.0 & $0.0 \mathrm{c}$ & $0.0 \mathrm{c}$ & $0.0 \mathrm{c}^{1}$ \\
\hline 2.28 & $0.0 \mathrm{c}$ & $0.0 \mathrm{c}$ & $0.0 \mathrm{c}$ \\
\hline 4.56 & $0.0 \mathrm{c}$ & $0.0 \mathrm{c}$ & $0.0 \mathrm{c}$ \\
\hline 9.12 & $0.0 \mathrm{c}$ & $1.0 \mathrm{c}$ & $0.5 \mathrm{c}$ \\
\hline 18.24 & $1.5 \mathrm{c}$ & $2.0 \mathrm{c}$ & $1.7 \mathrm{c}$ \\
\hline 27.36 & $5.0 \mathrm{~b}$ & $7.5 \mathrm{~b}$ & $6.2 \mathrm{~b}$ \\
\hline 45.60 & $13.7 \mathrm{a}$ & $18.7 \mathrm{a}$ & $16.2 \mathrm{a}$ \\
\hline $\mathrm{CV}(\%)$ & & & 69.21 \\
\hline \multicolumn{4}{|c|}{ Phytotoxicity at 7 DAT } \\
\hline 0.0 & $0.0 \mathrm{~b}$ & $0.0 \mathrm{c}$ & $0.0 \mathrm{c}$ \\
\hline 2.28 & $0.0 \mathrm{~b}$ & $0.7 \mathrm{c}$ & $0.3 \mathrm{c}$ \\
\hline 4.56 & $0.0 \mathrm{~b}$ & $1.7 \mathrm{c}$ & $0.8 \mathrm{c}$ \\
\hline 9.12 & $0.0 \mathrm{~b}$ & $2.7 \mathrm{c}$ & $1.3 \mathrm{bc}$ \\
\hline 18.24 & $0.7 \mathrm{~b}$ & $2.5 \mathrm{c}$ & $1.6 \mathrm{bc}$ \\
\hline 27.36 & $1.2 \mathrm{~b}$ & $5.5 \mathrm{~b}$ & $3.3 \mathrm{~b}$ \\
\hline 45.60 & $7.2 \mathrm{a}$ & $10.0 \mathrm{a}$ & $8.6 \mathrm{a}$ \\
\hline $\mathrm{CV}(\%)$ & & & 65.24 \\
\hline \multicolumn{4}{|c|}{ Phytotoxicity at 14 DAT } \\
\hline 0.0 & B $0.0 \mathrm{~b}$ & $\mathrm{~A} 0 \mathrm{~b}$ & $0.0 \mathrm{~b}$ \\
\hline 2.28 & B $0.0 \mathrm{~b}$ & $\mathrm{~A} 0 \mathrm{~b}$ & $0.0 \mathrm{~b}$ \\
\hline 4.56 & B $0.0 \mathrm{~b}$ & $\mathrm{AO} \mathrm{b}$ & $0.0 \mathrm{~b}$ \\
\hline 9.12 & B $1.0 \mathrm{~b}$ & $\mathrm{~A} 0 \mathrm{~b}$ & $0.5 \mathrm{~b}$ \\
\hline 18.24 & B $0.7 \mathrm{~b}$ & $\mathrm{AOb}$ & $0.3 \mathrm{~b}$ \\
\hline 27.36 & B $1.2 \mathrm{~b}$ & $\mathrm{AO} 0 \mathrm{~b}$ & $0.6 \mathrm{~b}$ \\
\hline 45.60 & A $8.0 \mathrm{a}$ & A 0 aa & $4.0 \mathrm{a}$ \\
\hline $\mathrm{CV}(\%)$ & & & 142.18 \\
\hline
\end{tabular}

Note. ${ }^{1}$ Means followed vertically by the same uppercase letter in rows and lowercase letter in lines do not differ by Tukey test at $5 \%$ probability.

For the herbicide 2,4-D, phytotoxicity symptoms of 20\%, which appeared 14 days after application of herbicide, were caused by the application of 77.29 and $109 \mathrm{~g}$ a.e. ha ${ }^{-1}$ at the stages V2, V5 and R2, respectively (Robinson et al., 2013). In a work using the maximum dose of 2,4-D (28 g a.e. ha $\left.^{-1}\right)$, the maximum phytotoxicity caused two weeks after the application at the V3 stage was 5\% and $0 \%$ at the R2 stage. Subsequent evaluations of symptoms were virtually absent (Solomon et al., 2014). In general, soybean was little affected by the 2,4-D. When 2,4-D is used at the highest doses at 7 and 14 DAT, the maximum phytotoxicity observed was 10\% when applied at both V3 and R2. At 28 DAT, it was not possible to observe symptoms caused by the herbicide.

\subsection{Soybean Height}

The application of the herbicide 2,4-D caused a decrease in the height of soybean plants only when evaluated at 28 DAT (Table 3). At 14 DAT and at ripening, no decrease in height was observed at both application stages. At 28 DAT, the subdoses $18.24,27.36$ and $45.60 \mathrm{~g}$ a.e. $\mathrm{ha}^{-1}$ negatively affected height by 7,11 and $17 \%$, respectively, in relation to the control. According to the evaluation at R2, there was no difference between the applied subdoses and the control. These results evidence a decreased soybean susceptibility to 2,4-D subdoses. In similar studies, decreases in the height of soybean plants were caused by the application of dicamba, mainly at the reproductive stages, and 2,4-D did not affect the vegetative or reproductive stages of soybean (Auch \& Arnold 1978; Kelley et al. 2005; Robinson et al. 2013). 
Table 3. Plant height (\%) of soybean plants at 14 and 28 days after application of treatments (DAT) and at ripening, cultivar Syngenta 13561 IPRO, in function of the application of subdoses of the herbicide 2,4-D choline salt and growth stages of soybean. Passo Fundo, RS, 2016

\begin{tabular}{|c|c|c|c|}
\hline \multirow{2}{*}{ Dose $\left(\right.$ g a.e. ha $\left.^{-1}\right)$} & \multicolumn{2}{|c|}{ Growth Stage } & \multirow{2}{*}{ Average } \\
\hline & V3 & R2 & \\
\hline \multicolumn{4}{|c|}{ Plant height at 14 DAT } \\
\hline 0.0 & $30.7^{\mathrm{ns}}$ & $88.4^{\mathrm{ns}}$ & $59.6^{\mathrm{ns}}$ \\
\hline 2.28 & 30.9 & 106.7 & 68.8 \\
\hline 4.56 & 30.3 & 86.0 & 58.1 \\
\hline 9.12 & 29.6 & 86.0 & 57.8 \\
\hline 18.24 & 30.1 & 84.7 & 57.4 \\
\hline 27.36 & 27.6 & 81.6 & 54.6 \\
\hline 45.60 & 25.2 & 84.7 & 55.0 \\
\hline $\mathrm{CV}(\%)$ & & & 13.4 \\
\hline \multicolumn{4}{|c|}{ Plant height at $28 D A T$} \\
\hline 0.0 & ${ }^{1} \mathrm{ABC} 64.4$ & $102.4^{\mathrm{ns}}$ & $83.4 \mathrm{abc}$ \\
\hline 2.28 & $\mathrm{ABC} 65.0$ & 99.60 & $82.3 \mathrm{abc}$ \\
\hline 4.56 & $\mathrm{ABC} 63.7$ & 99.80 & $81.7 \mathrm{abc}$ \\
\hline 9.12 & $\mathrm{ABC} 61.4$ & 99.90 & $80.7 \mathrm{abc}$ \\
\hline 18.24 & BCD 59.9 & 98.20 & $79.0 \mathrm{bcd}$ \\
\hline 27.36 & CDE 57.2 & 98.70 & $78.0 \mathrm{~cd}$ \\
\hline 45.60 & DCD 53.2 & 101.0 & $77.1 \mathrm{~d}$ \\
\hline $\mathrm{CV}(\%)$ & & & $2.81 \mathrm{ss}$ \\
\hline \multicolumn{4}{|c|}{ Plant heigh at Maturation } \\
\hline 0.0 & $97.7^{\mathrm{ns}}$ & $98.8^{\mathrm{ns}}$ & $98.2 \mathrm{a}$ \\
\hline 2.28 & 97.9 & 97.7 & $97.8 \mathrm{a}$ \\
\hline 4.56 & 96.8 & 97.7 & $97.3 \mathrm{a}$ \\
\hline 9.12 & 95.8 & 97.3 & $96.6 \mathrm{a}$ \\
\hline 18.24 & 94.4 & 94.1 & $94.2 \mathrm{ab}$ \\
\hline 27.36 & 91.1 & 97.7 & $94.4 \mathrm{ab}$ \\
\hline 45.60 & 87.8 & 95.1 & $91.5 \mathrm{~b}$ \\
\hline $\mathrm{CV}(\%)$ & & & 3.03 \\
\hline
\end{tabular}

Note. ${ }^{1}$ Means followed by the same uppercase letter in rows and lowercase letter in lines do not differ by Tukey test at $5 \%$ probability. ${ }^{\text {ns }}$ not significant at $5 \%$ level of probability.

\subsection{Yield Components}

The following yield components were determined: number of nodes, number of branches, weight of one thousand seeds (WTS), and number of pods. The application of 2,4-D was not statistically significant for all variables of yield components (Table 4). Thus, all subdoses used at both stages of development did not exert negative effects on the number of nodes, number of branches, weight of one thousand seeds, and number of pods. The application of 2,4-D only had a negative effect on yield components when doses higher than $84 \mathrm{~g}$ a.e. ha ${ }^{-1}$ were used. This dose was $84 \%$ higher than that used in this study (Robinson et al., 2013). Furthermore, the application of subdoses from 0 to $140 \mathrm{~g}$ a.e. $\mathrm{ha}^{-1}$ of 2,4-D did not decrease the number of nodes, pods, and seed mass (Wax et al., 1969). 
Table 4. Number of nodes (nodes plant ${ }^{-1}$ ), number of branches (branches plant ${ }^{-1}$ ), average length of branches ALB $\left(\mathrm{cm}^{-1}\right)$, weight of one thousand seeds $(\mathrm{g})$, number of pods (pods plant ${ }^{-1}$ ) and yield $\left(\mathrm{kg} \mathrm{ha}^{-1}\right)$ of soybean, cultivar Syngenta 13561 IPRO, in function of the application of subdoses of the herbicide 2,4-D choline salt and growth stages of soybean. Passo Fundo, RS, 2016

\begin{tabular}{llllll}
\hline Dose $\left(\right.$ g a.e. $\left.^{-1}\right)$ & Nodes & Branches & ALB & Pods & Yield \\
\hline 0.0 & $17.5^{\mathrm{ns}}$ & $1.12^{\mathrm{ns}}$ & $160.9^{\mathrm{ns}}$ & $44.5^{\mathrm{ns}}$ & $4,709.2^{\mathrm{ns}}$ \\
2.28 & 17.1 & 1.9 & 167.3 & 41.1 & $4,740.2$ \\
4.56 & 17.8 & 2.3 & 167.1 & 46.8 & $4,894.3$ \\
9.12 & 17.5 & 1.8 & 161.1 & 44.0 & $4,661.1$ \\
18.24 & 17.4 & 1.4 & 171.0 & 42.7 & $4,966.8$ \\
27.36 & 16.8 & 1.6 & 168.5 & 40.4 & $4,800.8$ \\
45.60 & 17.1 & 1.8 & 164.5 & 41.0 & $4,679.9$ \\
CV $(\%)$ & 5.5 & 66.4 & 5.5 & 15.2 & 8.36 \\
Growth Stage & & & & \\
V3 & $17.3^{\mathrm{ns}}$ & $1.8^{\mathrm{ns}}$ & $167.3^{\mathrm{ns}}$ & $43.2^{\mathrm{ns}}$ & $4,793.9^{\mathrm{ns}}$ \\
R2 & 17.4 & 1.6 & 164.3 & 42.6 & $4,763.9^{\mathrm{ns}}$ \\
CV $(\%)$ & 9.74 & 38.71 & 4.36 & 25.14 & 8.36 \\
\hline
\end{tabular}

Note. ${ }^{\mathrm{ns}}$ not significant at $5 \%$ error probability.

\subsection{Grain Yield}

Soybean grain yield was not negatively influenced by both application times and 2,4-D herbicide subdoses (Table 4). In a study conducted by Robinson et al. (2013), soybean grain yield decreased by 5\% using the subdose $116 \mathrm{~g}$ a.e. $\mathrm{ha}^{-1}$ and by $10 \%$ using the subdose $202 \mathrm{~g}$ a.e. $\mathrm{ha}^{-1}$ at both V2 and R2. These results indicate that, by using the 2,4-D subdoses proposed by this work, the soybean grain yield does not decrease. The results of soybean yield of this work are different from those reported in the literature (Andersen et al., 2004; Slife, 1956; Wax et al., 1969). Such differences can be explained by the variation in tolerance to 2,4-D of different soybean cultivars (Friborg \& Johnson, 1955).

With this work, the 2,4-D at the subdoses up to $45.60 \mathrm{~g}$ a.e. $\mathrm{ha}^{-1}$, representing $5 \%$ of the commercial dose, represented in this work by $912 \mathrm{~g}$ a.e. $\mathrm{ha}^{-1}$, is not enough to cause significant phytotoxicity or changes in yield components that could influence crop yield. Noteworthy is the rainfall index that occurred during the crop cycle (Figure 1). It is possible to observe that rainfall was higher than the average in all months, making a positive contribution to the crop from the point of view of damage recovery and metabolizing of herbicides (Shaner, 2014).

The visual assessment of phytotoxicity may be subjective to the point of becoming variable, making this method often less reliable. Thus, a thorough evaluation, although slow, and the evaluation of yield components can make the results of the work more accurate by indicating in which cases the cause of the decrease in crop yield occurs. Many other cultures are sensitive to 2,4-D and dicamba drifts or residues, such as vines, smoke, and tomato (Constantin et al., 2007; Oliveira Jr., 2007).

\section{Conclusions}

2,4-D tank residues up to $45.60 \mathrm{~g}$ a.e. ha $^{-1}$ equivalent to $5 \%$ of commercial rate, do not decrease soybean yield. Thus, care must be taken for a correct cleaning of spray tanks before applying products to soybean plants that are not tolerant to certain herbicides. Although sprays with 2,4-D residues in susceptible soybeans may occur, it is important to note that all necessary precautions should be taken in view of the difficulty of measuring the amount of residue present in the tank.

\section{References}

Andersen, S. A., Clay, S. A., Wrage, L. J., \& Matthees, D. (2004). Soybean foliage residues of dicamba and 2,4-D and correlation to application rates and yield. Agronomy Journal, 96, 750-760. https://doi.org/ 10.2134/agronj2004.0750

Auch, D. E., \& Arnold, W. E. (1978). Dicamba use and injury on soybean (Glycine max) in South Dakota. Weed Science, 26, 471-475. https://doi.org/10.1017/S0043174500050347

Behrens, M. R., Mutlu, N., Chakraborty, S., Dumitru, R., Jiang, W. Z., Lavallee, B. J., ... Weeks, D. P. (2007). Dicamba resistance: Enlarging and preserving biotechnology-based weed management strategies. Science, 316, 1185-1188. https://doi.org/10.1126/science.1141596 
Constantin, J., Oliveira Júnior, R. S. de., Fagliari, J. R., Pagliari, P. H., Arantes, J. G. Z., Cavalieri, S. D., ... Gonçalves, D. A. (2007). Effect of sub-lethal dosages of 2,4-D on cotton yield and crop susceptibility as a function of its development stage. Engenharia Agrícola, 27, 24-29. https://doi.org/10.1590/S0100-6916200 7000200004

Embrapa (Empresa Brasileira de Pesquisa Agropecuária). (2006). Sistema Brasileiro de Classificação de Solos (2nd ed., p. 412). Rio de Janeiro: Embrapa SPI.

Embrapa (Empresa Brasileira de Pesquisa Agropecuária). (2016). Normais Climatológicas (1961/1990). Passo Fundo-RS. Retrieved from http://www.cnpt.embrapa.br/pesquisa/agromet/app/principal/normais.php

Frans, R., Talbert, R., Marx, D., \& Crowley, H. (1986). Experimental design and techniques for measuring and analyzing plant responses to weed control practices. In N. D. Camper (Ed.), Research methods in weed science (3rd ed., p. 37). Champaign: Southern Weed Science Society.

Fribourg, H. A., \& Johnson, I. J. (1955). Response of soybean strains to 2,4-D and 2,4,5-T. Agronomy Journal, 47, 171-174. https://doi.org/10.2134/agronj1955.00021962004700040006x

Green, J. M., \& Castle, L. A. (2010). Transitioning from single to multiple herbicide-resistant crops. In V. K. Nandula (Ed.) Glyphosate resistance in crops and weeds: History, development, and management (p. 91). Wiley, Hoboken, NJ. https://doi.org/10.1002/9780470634394.ch4

Grossmann, K. (2010). Auxin herbicides: Current status of mechanism and mode of action. Pest Management Science, 66, 113-120. https://doi.org/10.1002/ps.1860

Kelley, K. B., Lambert, K. N., Hager, A. G., \& Riechers, D. G. (2004). Quantitative expression analysis of GH3, a gene induced by plant growth regulator herbicides in soybean. Journal of Agriculture, Food and Chemistry, 52, 474-478. https://doi.org/10.1021/jf0351341

Kelley, K. B., Wax, L. M., Hager, A. G., \& Riechers, D. E. (2005). Soybean response to plant growth regulator herbicides is affected by other post emergence herbicides. Weed Science, 53, 101-112. https://doi.org/ 10.1614/WS-04-078R

Oliveira Júnior, R. S., Constantin, J., Brandão, J. U. T., Cavalieri, S. D., Framesqui, V. P., Carreira, S. A. M., \& Roso, A. C. (2007). Efeito de subdoses de 2,4-D na produtividade de uva Itália e susceptibilidade da cultura em função de seu estádio de desenvolvimento. Engenharia Agrícola, 27, 35-40. https://doi.org/10.1590/ S0100-69162007000200006

Olszyk, D., Pfleeger, T., Lee, E. H., \& Plocher, M. (2015). Glyphosate and dicamba herbicide tank mixture effects on native plant and non-genetically engineered soybean seedlings. Ecotoxicology, 24, 1014-1027. https://doi.org/10.1007/s10646-015-1442-8

Robinson, A. P., Davis, V. M., Simpson, D. M., \& Johnson, W. G. (2013). Response of Soybean Yield Components to 2,4-D. Weed Science, 61, 68-76. https://doi.org/10.1614/WS-D-12-00077.1

Shaner, D. L. (2014). Herbicide handbook (10th ed., p. 513). Weed Science Society of America, Champaign, IL.

Slife, F. W. (1956). The effect of 2,4-D and several other herbicides on weeds and soybeans when applied as post-emergence sprays. Weeds, 4, 61-68. https://doi.org/10.2307/4040010

Solomon, C. B., \& Bradley, K. W. (2014). Influence of application timings and sublethal rates of synthetic auxin herbicides on soybean. Weed Technology, 28, 454-464. https://doi.org/10.1614/WT-D-13-00145.1

Vink, J. P., Soltani, N., Robinson, D. E., Tardif, F. J., Lawton, M. B., \& Sikkema, P. H. (2012). Glyphosate-resistant giant ragweed (Ambrosia trifida) control in dicamba-tolerant soybean. Weed Technology, 26, 422-428. https://doi.org/10.1614/WT-D-11-00184.1

Wax, L. M., Knuth, L. A., \& Slife, F. W. (1969). Response of soybeans to 2,4-D, dicamba, and picloram. Weed Science, 17, 388-393. https://doi.org/10.1017/S004317450005431X

\section{Copyrights}

Copyright for this article is retained by the author(s), with first publication rights granted to the journal.

This is an open-access article distributed under the terms and conditions of the Creative Commons Attribution license (http://creativecommons.org/licenses/by/4.0/). 